\title{
Magnesium oxide-impregnated tuff soil-derived ceramic: a novel cadmium(II) adsorbing media
}

\author{
Md Salim ${ }^{1,5} \cdot$ Jatindra N. Bhakta ${ }^{2,3,4,5}$ - Namburath Maneesh ${ }^{5}$. \\ Yukihiro Munekage $^{5} \cdot$ Kevin Motomura $^{1}$
}

Received: 27 February 2015/ Accepted: 7 July 2015/Published online: 22 July 2015

(c) The Author(s) 2015. This article is published with open access at Springerlink.com

\begin{abstract}
The contamination of cadmium $(\mathrm{Cd})$ in the aquatic environment is one of the serious environmental and human health's risks. The present study attempted to develop the potential magnesium oxide ( $\mathrm{MgO})$-impregnated tuff soil-derived ceramic (MITDC)-based novel adsorbent media for adsorbing higher rate of cadmium [Cd(II)] from water phase. A potential MITDC adsorbent media was developed using volcanic raw tuff soil and its $\mathrm{Cd}(\mathrm{II})$ adsorption capacity from water phase was evaluated comparing with the raw tuff soil. A series of studies were carried out in an agitated batch method at $20 \pm 2{ }^{\circ} \mathrm{C}$ to characterize the adsorption capacity of MITDC under different conditions of factors, such as contact time (0-360 min), initial pH (3-11) of solution, dose of MITDC $(2,5,7.5$ and $10 \mathrm{~g} / \mathrm{L})$, and initial concentration of $\mathrm{Cd}(\mathrm{II})$ $(5,10,20,30$, and $40 \mathrm{mg} / \mathrm{L})$, influencing the adsorption mechanism. MITDC exhibited the equilibrium state of maximum $\mathrm{Cd}(\mathrm{II})$ adsorption at the contact time $120 \mathrm{~min}$ and $\mathrm{pH} 4.7$ (removed $98.2 \% \mathrm{Cd}$ ) when initial $\mathrm{Cd}(\mathrm{II}$ ) concentration was $10 \mathrm{mg} / \mathrm{L}$ in the present study. The dose
\end{abstract}

Jatindra N. Bhakta

lsnjbhakta@gmail.com

1 AGAT Laboratories (Mining Geochemistry), 5623 McAdam Rd, Mississauga, ON L4Z 1N9, Canada

2 International Centre for Ecological Engineering, University of Kalyani, Kalyani, West Bengal 741235, India

3 Ramnagar Institute of Rural Human Resource Development, Purba Medinipur, West Bengal 721453, India

4 Heritage Foundation, 198/7 M.G. Road, Thakurpukur, Kolkata, West Bengal 700063, India

5 Department of Environmental Engineering, Faculty of Agriculture, Kochi University, B200, Monobe, Nankoku, Kochi 783-8502, Japan of $7.5 \mathrm{~g}$ MITDC/L showed maximum removal of $\mathrm{Cd}(\mathrm{II})$ from water. Experimental data were described by the Freundlich and the Langmuir isotherms and equilibrium data fitted well with the Langmuir model $\left(R^{2}=0.996\right)$. The Cd(II) adsorption capacity of MITDC was $31.25 \mathrm{mg} / \mathrm{g}$. The high Cd(II) adsorption capacity indicated that novel MITDC could be used as a potential ceramic adsorbent media to remove high rate of $\mathrm{Cd}(\mathrm{II})$ from aqueous phase.

Keywords Magnesium oxide - Tuff soil - Impregnation · Cadmium ion $\cdot$ Adsorption $\cdot$ Isotherm

\section{Introduction}

Heavy metals are nonbiodegradable hazardous priority pollutants (Tewari et al. 2005; Bayrak et al. 2006) having significant properties of bioaccumulation and biomagnification. Indiscriminate and uncontrolled discharge of hazardous heavy metals into the environment by means of anthropogenic as well as geogenic activities leads to the contamination of water, soil, and air. The heavy metal contamination bas been identified as one of the prime environmental problems worldwide due to posing hazardous and detrimental impacts on all forms of life (Kratochvil and Volesky 1998; Gupta and Gupta 1998; Aksu 2005; Bolger and Szlag 2002; Bidstrup 1964; Lin et al. 2000).

Cadmium (Cd) is one of the biologically nonessential, nonbiodegradable, persistent type of priority hazardous and heavy metal pollutants (Campbell 2006), which easily accumulates in sediments and aquatic organisms (by bioaccumulation and biomagnifications), and thus causing a gross biological impact. It is poisonous for plants, animals, and humans (Gupta and Gupta 1998) and recognized 
as a human carcinogen (IARC 1994). Human exposure to low level of $\mathrm{Cd}$ can result in renal diseases, osteomalacia, and lung cancer as well as damage the cardiovascular system, liver, and reproductive system (USEPA 1992; Hrudey et al. 1995; Belimov et al. 2005). Excessive intake of $\mathrm{Cd}$ leads to damage of human enzyme tissue, lung, kidney and renal system, skeletal deformation (Japanese itai-itai diseases), cardiovascular diseases, and hypertension (Nogawa et al. 2004; Argun et al. 2007).

Mining and smelting processes of lead and zinc, nickelcadmium batteries, polyvinyl chloride plastics, paint pigments, insecticides, fungicides, and commercial fertilizer industries are the primary sources for causing $\mathrm{Cd}$ contamination as well as for causing the aforesaid tremendous environmental and human health risks. However, the effluent of $\mathrm{Cd}$ is a big environmental problem, since $\mathrm{Cd}$ is variously used as important component in producing different commodities required for daily life of human. In recent years, therefore, $\mathrm{Cd}$ removal from industrial wastewater is an important issue. Various technologies, chemical precipitation, ion exchange, membrane filtration, carbon adsorption, and co-precipitation, have been developed for the removal of heavy metals and many other pollutants (such as dyes) from aqueous solution over the years (Kentish and Stevens 2001, Saleh and Gupta 2012a, Gupta et al. 2012a, b). Adsorption is one of the effective techniques in removing $\mathrm{Cd}$ from wastewater (Aggarwal et al. 1999; Bhakta and Munekage 2009) because its sorption process largely depends on surface area, porous character, and chemical nature of adsorbent. Various relatively low-cost adsorbents have been developed and used for the removal of $\mathrm{Cd}$ and other various heavy metals [Such as Lead $(\mathrm{Pb})$, Mercury $(\mathrm{Hg})$, Cupper $(\mathrm{Cu})$, etc.] from aqueous solution (Sari and Tuzen 2009) such as silica ceramic (Salim et al. 2008), chitin (Benguella and Benaissa 2002), wood (Rafatullah et al. 2012), granular red mud (GRM) (Zhu et al. 2007a, b), fertilizer waste-derived activated carbon (Gupta et al. 1998), $\mathrm{Mn}_{2} \mathrm{O}$-loaded D301 resin MITDC and RT (Zhu et al. 2007a, b), alumina-coated multiwalled carbon nanotubes (Gupta et al. 2011), and manganese dioxide-coated multiwalled carbon nanotube (Saleh and Gupta 2012b). Soil, mud, waste materials, and its derivatives have great potential as inexpensive and efficient sorbents of various pollutants including metals and dyes due to their easy availability, chemical and mechanical stability, high surface area, and favorable structural properties (Gupta et al. 1998, Mittal et al. 2009a, b, 2010, Mittal et al. 2010, Vakili et al. 2014). Bhakta and Munekage (2013) identified some soil adsorbents including tuff soil (Meadow soil association, Japan) as potential media for removing hazardous metal(loid)s (cadmium, lead, and arsenic) from water phase. The studies also proved the ceramics derived from soil is a promising media for removing heavy metals from water (Bhakta and Munekage 2009; Bhakta et al. 2009). There is an upsurge of interest in recent years to utilize natural minerals for the remediation of Cd-contaminated environment (Gupta and Bhattacharyya 2006; Lackovic et al. 2004). It has also been proposed that tuff soil has high $\mathrm{Cd}$ removal ability from water (Bhakta and Munekage 2013). However, no study has been attempted so far to develop the magnesium oxide (MgO)-impregnated tuff soil-based low-cost ceramic adsorbent media in order to remove the high rate of $\mathrm{Cd}$ from aqueous medium. Therefore, this study has firstly attempted to develop a potential tuff soil-based low-cost novel ceramic adsorbent media impregnating $\mathrm{MgO}$ for the removal of higher rate of $\mathrm{Cd}$ (II) from aqueous phase. The higher $\mathrm{Cd}(\mathrm{II})$ removal capacity of developed ceramic was evaluated comparing with the raw tuff (RT) under different conditions of physicochemical factors influencing the adsorption mechanism.

\section{Materials and methods}

\section{Chemicals}

The present study used the following chemicals: hydrochloric acid $(\mathrm{HCl})$, sodium hydroxide $(\mathrm{NaOH})$, magnesium oxide $(\mathrm{MgO})$, and cadmium chloride $\left(\mathrm{CdCl}_{2}\right)$ were purchased from Nacalai Tesque, Inc. and Kanto Chemical Co., Inc., Tokyo, Japan. All synthetic and stock solutions were prepared using milli $\mathrm{Q}$ water of Millipore (Millipore, MA, USA).

\section{Synthesis of magnesium oxide (MgO)-impregnated tuff soil-derived ceramic (MITDC)}

Volcanic raw tuff soil (consists of ash, fragments of rock, and other miscellaneous materials) was obtained from Shimane peninsula, Japan and used for preparation of MgO-impregnated tuff soil-derived ceramic (MITDC) according to the following procedure: raw tuff (RT) soil $\left[\mathrm{CaO}(65.36 \%), \mathrm{SiO}_{2}(21.83 \%), \mathrm{FeO}(7.7 \%), \mathrm{Al}_{2} \mathrm{O}_{3}\right.$ $(4.13 \%)$, and $\mathrm{MgO}(1.29 \%)$; specific surface area $8.69 \mathrm{~m}^{2} / \mathrm{g}$ ] was dried by oven at $110^{\circ} \mathrm{C}$ for $4 \mathrm{~h}$, ground, and sieved to get uniform granules of RT. A screening process was performed in order to select the metal oxide having the high $\mathrm{Cd}$ (II) removal capacity (data not shown), and magnesium oxide $(\mathrm{MgO})$ was selected as high $\mathrm{Cd}(\mathrm{II})$ up taking agent among the metal oxides tested. The selected magnesium oxide $(\mathrm{MgO})$ was mixed with tuff soil at the rate of 2,5 , and $10 \%$ to determine the best impregnation dose of $\mathrm{MgO}$. The soft dough of tuff soil and $\mathrm{MgO}$ mixture was made by adding distilled water. Finally, the dough was air dried for $48 \mathrm{~h}$ and burned in different 
temperatures 300,700 , and $900{ }^{\circ} \mathrm{C}$ for $5 \mathrm{~h}$ in order to activate and obtain the ceramic structure. After cooling, the hard composites of three $\mathrm{MgO}$ percentages $(2,5$ and $10 \%$ ) were ground, sieved to get an equal particle size, and stored in capped glass bottles for screening and selection of optimum percent of $\mathrm{MgO}$ and activation temperature. Further a screening study determined that $5 \% \mathrm{MgO}-\mathrm{im}$ pregnated tuff soil-derived ceramic activated by $700{ }^{\circ} \mathrm{C}$ (herein called as MITDC) was the best for removing high rate of $\mathrm{Cd}(\mathrm{II})$ from aqueous solution (data not shown). Similar process was followed to develop the adsorbent media used for removing $\mathrm{Cd}(\mathrm{II})$ by adsorption on GRM (Zhu et al. 2007a, b) and mercury (Bhakta and Munekage 2011) from aqueous solutions.

\section{Physical and chemical properties}

The morphological properties and chemical composition of RT and MITDC were analyzed by scanning electron microscopy and energy dispersive spectroscopy (SEMEDS, JEOL-JSM-6500F, Tokyo, Japan) in the Center for Advanced Marine Core Research, Kochi University, Japan using the process followed by Bhakta and Munekage (2013). Specific surface area of the RT particles (as shown in Synthesis of MITDC section) was measured by means of specific surface analyzer [YUASA-IONICS NOVA 2000].

\section{Batch adsorption experiments}

The Cd(II) adsorption experiments were carried out using a batch equilibrium technique to determine the optimum process parameters required for maximum $\mathrm{Cd}(\mathrm{II})$ adsorption of MITDC and RT from water. Experiments were conducted in 200-mL capped glass bottles using known weight of the adsorbents to equilibrate the known volume of adsorbate $(100 \mathrm{~mL})$. The effect of contact periods was determined by maintaining the initial concentration $10 \mathrm{mg} /$ $\mathrm{L}$, pH 5.6, and adsorbent dose $0.5 \mathrm{~g} / \mathrm{L}$. The effects of different initial $\mathrm{pH}(3-11)$ values on the $\mathrm{Cd}$ adsorption of adsorbents were determined by adjusting the $\mathrm{pH}$ (by $0.1 \mathrm{~N}$ $\mathrm{HCl}$ and $0.1 \mathrm{~N} \mathrm{NaOH}$ ) and maintaining the conditions, initial concentration of $\mathrm{Cd}(\mathrm{II}) 10 \mathrm{mg} / \mathrm{L}$ and adsorbent dose $5 \mathrm{~g} / \mathrm{L}$. The effects of adsorbent dosages were determined using 2, 5, 7.5 and $10 \mathrm{~g} / \mathrm{L}$ of adsorbent and $10 \mathrm{mg} / \mathrm{L}$ of adsorbate $[\mathrm{Cd}(\mathrm{II})]$ solution with $\mathrm{pH}$ 5.6. To determine the effects of initial adsorbate concentrations, the initial $\mathrm{Cd}(\mathrm{II})$ concentrations of $5,10,20,30$, and $40 \mathrm{mg} / \mathrm{L}$ with $\mathrm{pH} 5.6$ and adsorbent dose of $0.5 \mathrm{~g} / \mathrm{L}$ were used. Each experiment was performed at least twice following the identical conditions using controls of only $\mathrm{Cd}$ (II) solution and adsorbents (MITDC and RT) without metals in solution. All experiments were conducted using the $\mathrm{Cd}(\mathrm{II})$ solution prepared from standard stock solution of $\mathrm{CdCl}_{2}$. In each experiment, the capped glass bottles were shaken by mechanical shaker at the rate of 150 excursion/min within the thermostat incubator at $20 \pm 2{ }^{\circ} \mathrm{C}$.

\section{Sampling and analysis}

The samples $(1 \mathrm{~mL})$ were collected from glass bottles, filtered by $0.20 \mu \mathrm{m}$ filter, centrifuged, and analyzed using an atomic absorption spectrometer (AAS 200, PerkinElmer) with $228.8 \mathrm{~nm}$ analytical wavelength of $\mathrm{Cd}(\mathrm{II})$ to determine the residual metal concentration in samples. Mean data obtained from least two experiments were used for analysis.

The amounts of $\mathrm{Cd}(\mathrm{II})$ adsorbed onto the MITDC and RT $(\mathrm{mg} / \mathrm{g})$ at the equilibrium state $\left(q_{\mathrm{e}}\right)$ and at specific time $\left(q_{\mathrm{t}}\right)$ were calculated by following the Eqs. 1 and 2 of mass balance relationship (Rozada et al. 2008; Bhakta and Munekage 2013; Bhakta et al. 2014a, b):

$q_{\mathrm{e}}(\mathrm{mg} / \mathrm{g})=\left[\frac{c_{\mathrm{i}}-c_{\mathrm{e}}}{M}\right] \times V$

$q_{\mathrm{t}}(\mathrm{mg} / \mathrm{g})=\left[\frac{c_{\mathrm{i}}-c_{\mathrm{t}}}{M}\right] \times V$,

where $q_{\mathrm{e}}(\mathrm{mg} / \mathrm{g})$ is the amount of $\mathrm{Cd}(\mathrm{II})$ adsorbed per gram of the adsorbent, $C_{\mathrm{i}}(\mathrm{mg} / \mathrm{L})$ is the initial concentration of $\mathrm{Cd}(\mathrm{II})$ in the solution, $C_{\mathrm{t}}(\mathrm{mg} / \mathrm{L})$ is the concentration of $\mathrm{Cd}(\mathrm{II})$ in the solution at time $t, C_{\mathrm{e}}(\mathrm{mg} / \mathrm{L})$ the equilibrium concentration of the solution of $\mathrm{Cd}(\mathrm{II}), V(\mathrm{~L})$ is the volume of the solution, and $M(\mathrm{~g})$ is the mass of the adsorbent.

The percentages of $\mathrm{Cd}(\mathrm{II})$ removed $\left(\mathrm{R}_{\mathrm{e}}\right)$ by the MITDC and RT were determined using the following Eq. 3:

$R_{\mathrm{e}}(\%)=\left[\frac{c_{\mathrm{i}}-c_{\mathrm{e}}}{c_{\mathrm{i}}}\right] \times 100$,

where $R_{\mathrm{e}}$ is the percentage (\%) of $\mathrm{Cd}(\mathrm{II})$ adsorbed, and $C_{\mathrm{i}}$ and $C_{\mathrm{e}}$ are the initial and equilibrium concentration of $\mathrm{Cd}(\mathrm{II})(\mathrm{mg} / \mathrm{L})$ in the solution, respectively.

\section{Results and discussion}

\section{Physical and chemical properties}

The SEM images of RT and MITDC shown in Fig. 1 are representing their morphological properties. The microscopic images $(10,000 \times)$ clearly reveal the elaborate surface structures of RT and MITDC. The MITDC surface structure was granular, whereas RT showed more smooth surface structure. The EDS analysis indicates that RT is composed of $\mathrm{CaO}(65.36 \%), \mathrm{SiO}_{2}(21.83 \%)$, $\mathrm{FeO}$ $(7.7 \%), \mathrm{Al}_{2} \mathrm{O}_{3}(4.13 \%)$, and $\mathrm{MgO}(1.29 \%)$ and MITDC is constituted by $\mathrm{CaO}(63.21 \%), \mathrm{SiO}_{2}(19.6 \%), \mathrm{FeO}$ (6.84\%), $\mathrm{Al}_{2} \mathrm{O}_{3}(4.03 \%)$, and $\mathrm{MgO}(6.04 \%)$. 

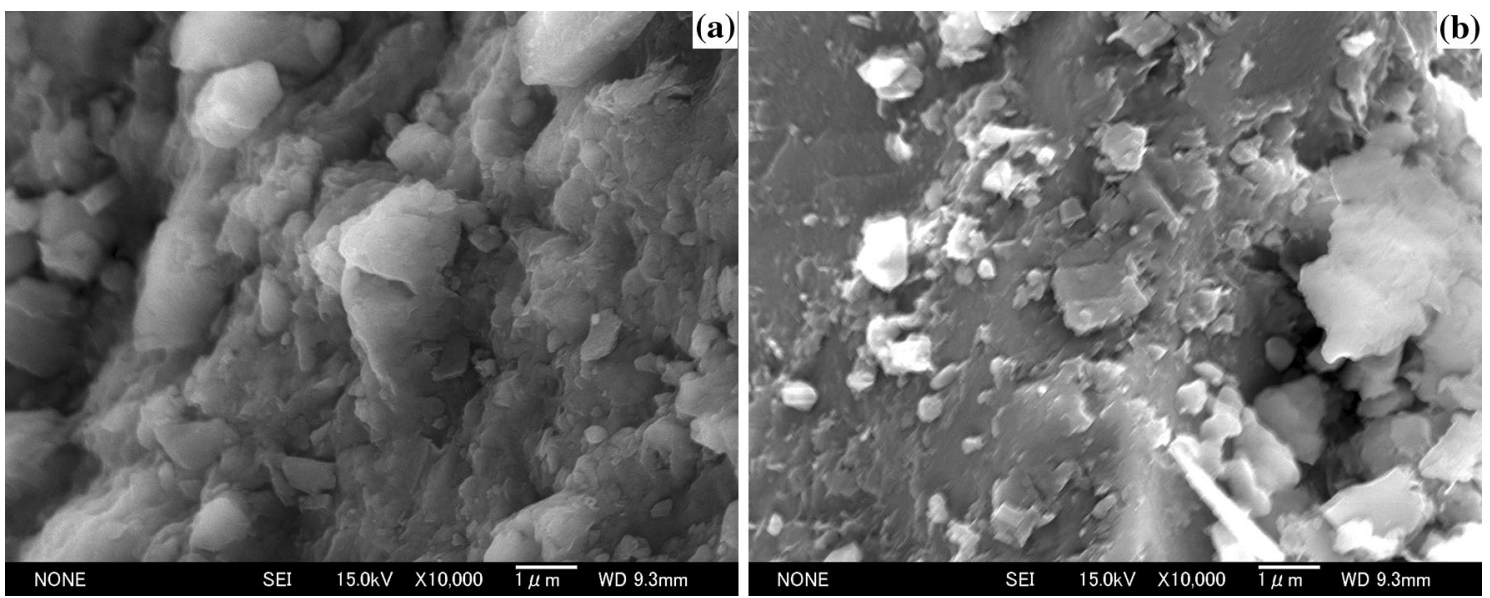

Fig. 1 SEM microimages $(10000 \times)$ of RT (a) and MITDC (b)

It may be suggested that impregnated $\mathrm{MgO}(5 \%)$ formed granular crystal structure by thermal $\left(700{ }^{\circ} \mathrm{C}\right)$ activation in MITDC.

\section{Effect of contact time}

The effect of contact time on the adsorption of $\mathrm{Cd}(\mathrm{II})$ onto the MITDC and RT is shown in Fig. 2. The metal adsorption is rapid in the first 90 and $30 \mathrm{~min}$ of contact period for MITDC and RT, respectively. The necessary optimum times were about $120 \mathrm{~min}$ for MITDC and $90 \mathrm{~min}$ for RT to reach the equilibrium state. Beyond these contact times, the amount of $\mathrm{Cd}(\mathrm{II})$ adsorbed on the MITDC and RT remained constant as shown in Fig. 2. The amounts of $\mathrm{Cd}(\mathrm{II})$ adsorbed at equilibrium are $16.6 \mathrm{mg} / \mathrm{g}$ for MITDC and $1.98 \mathrm{mg} / \mathrm{g}$ for RT in this experiment. The amount of $\mathrm{Cd}$ (II) adsorbed onto MITDC was much higher than the values obtained by RT at the same interaction time period (360 min). These observations are similar with the works of Alemayehu and Lennartz (2009), Benaissa (2006), and Benguella and Benaissa (2002).

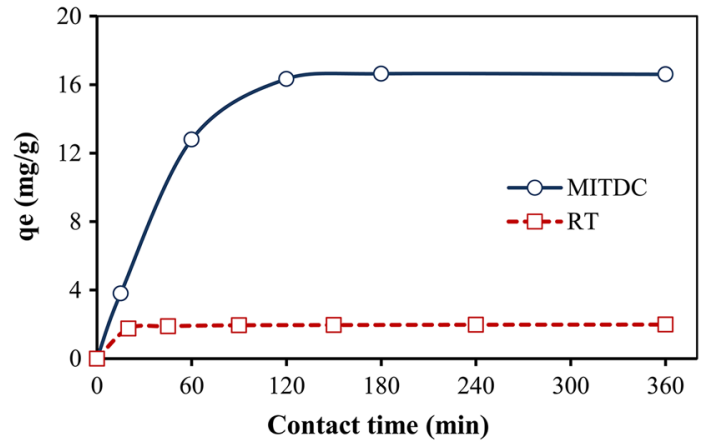

Fig. 2 Effect of contact time on adsorption of Cd(II) by MITDC and RT (initial concentration of $\mathrm{Cd}$ (II) $10 \mathrm{mg} / \mathrm{L}, \mathrm{pH} 5.6$, adsorbent dose $0.5 \mathrm{~g} / \mathrm{L})$

\section{Effect of solution $\mathrm{pH}$}

The effects of different $\mathrm{pH}$ values on adsorption efficiency of MITDC and RT are represented in Fig. 3. The removal efficiency was high between the $\mathrm{pH} 4$ and 8 and slightly decreased at $\mathrm{pH} 9$ and increased with increasing $\mathrm{pH}$ thereafter in MITDC and RT. The MITDC showed maximum removal $(98.2 \%)$ at a $\mathrm{pH}$ value of 4.7 , whereas $\mathrm{RT}$ exhibited highest adsorption of $\mathrm{Cd}(\mathrm{II})$ at 7.1 and 10.5. It indicated that though favorable adsorption takes place at $\mathrm{pH} 4.3-8$, optimum $\mathrm{pH}$ would be 4.7 for MITDC to remove maximum $\mathrm{Cd}(\mathrm{II})$. In relation to the $\mathrm{Cd}$ speciation diagram, $\mathrm{Cd}(\mathrm{II})$ is the predominant ionic species at $\mathrm{pH}$ less than 7 (Baes and Mesmer 1986). Similar results were reported for the adsorption of $\mathrm{Cd}(\mathrm{II})$ from aqueous phase onto eucalyptus bark (Ghodbane et al. 2008) and manganese oxideloaded resin (Zhu et al. 2007a, b). Considering the above results, it is fact that the effect of $\mathrm{pH}$ in the sorption process of sorbent can be explained by the surface charge of adsorbent materials and the specification of $\mathrm{Cd}(\mathrm{II})$. Srivastava (2013) reported that the effect of solution $\mathrm{pH}$ can

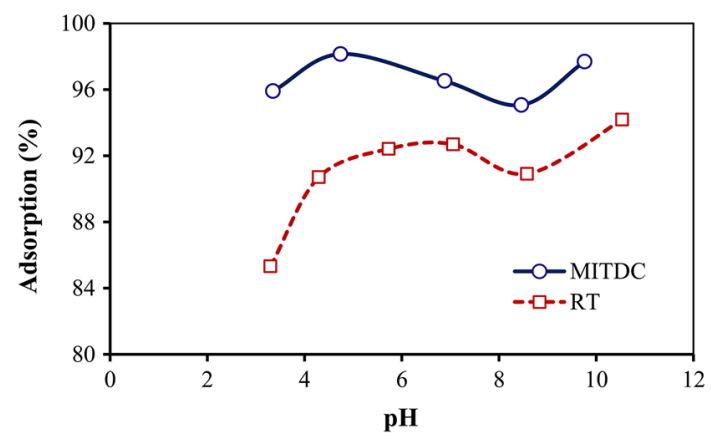

Fig. 3 Effect of $\mathrm{pH}$ on the adsorption of Cd(II) by MITDC and RT. (Initial concentration of $\mathrm{Cd}(\mathrm{II}) 10 \mathrm{mg} / \mathrm{L}$, contact time $120 \mathrm{~min}$, adsorbent dose $5 \mathrm{~g} / \mathrm{L}$ ) 
be explained by considering the surface charge of the carbon nanotubes and the degree of ionization and speciation of the sorbates.

\section{Effect of adsorbent dose}

Figure $4 \mathrm{a}$ and $\mathrm{b}$ elucidates the effects of different adsorbent dosages on the $\mathrm{Cd}(\mathrm{II})$ adsorption of MITDC and RT. The removal efficiency was higher in MITDC (85-95\%) than that of the RT (30-40\%) within the 15 min contact time. It can be seen in the Fig. $4 \mathrm{~b}$ that the percentage of $\mathrm{Cd}(\mathrm{II})$ removal increased sharply up to adsorbent dose $7.5 \mathrm{mg} / \mathrm{L}$ and steady thereafter. It demonstrated that the adsorbent dose $7.5 \mathrm{mg} / \mathrm{L}$ is optimum for maximum $\mathrm{Cd}(\mathrm{II})$ adsorption in the experiment. It is due to the increased available surface area of adsorbent in the higher adsorbent doses, and thus, high amount of $\mathrm{Cd}(\mathrm{II})$ is attached to their surfaces (Gupta and Bhattacharyya 2006). The results also demonstrated that though total $\mathrm{Cd}(\mathrm{II})$ adsorption increased with increasing the dosages, the amount of adsorption per gram of ceramic (i.e., $q_{\mathrm{e}}$ ) was higher in lower dosages than that of the higher dosages in this experiment. The decreasing trend of $q_{\mathrm{e}}$ value with the increasing adsorbent dosages may result from the electrostatic interactions, interference
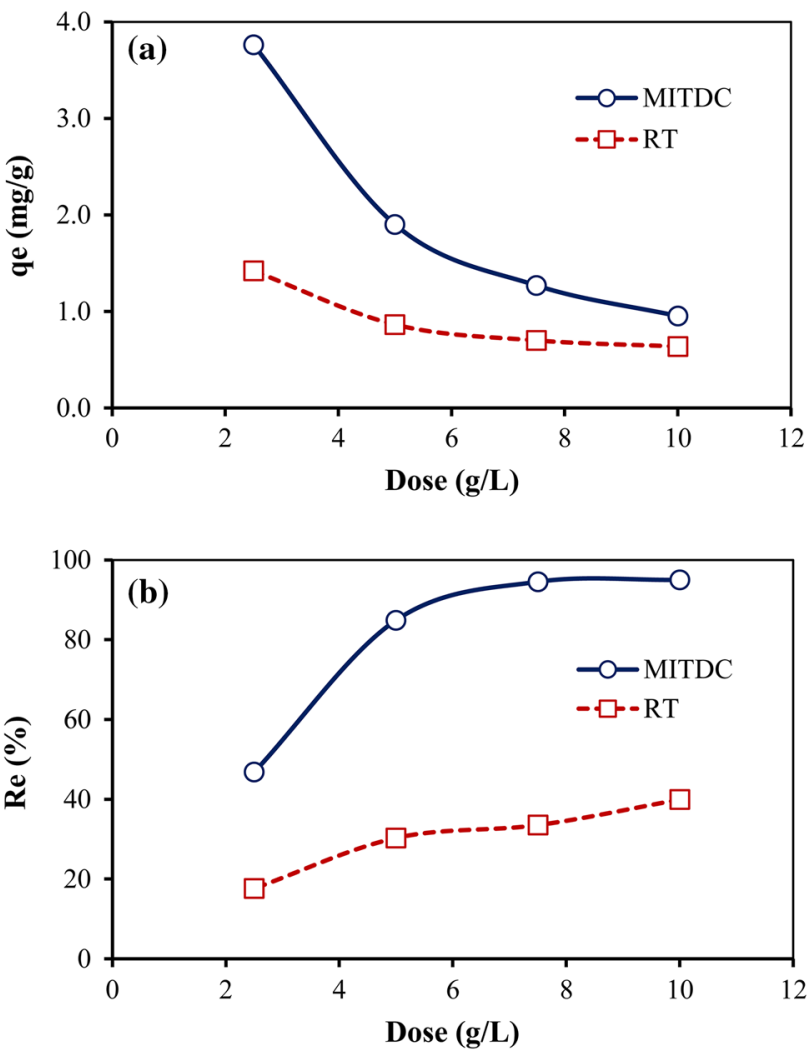

Fig. 4 Effect of adsorbent dose on adsorption of Cd(II) by MITDC and RT (pH 5.6, Cd(II) concentration $10 \mathrm{mg} / \mathrm{L}$ ); $\mathbf{a} q_{\mathrm{e}}$ vs dose and $\mathbf{b} R_{\mathrm{e}}$ vs dose between binding sites, and reduced mixing for higher densities at higher dosages of adsorbent (Fourest and Roux 1992; Montanher et al. 2005). It is also obvious that the competition between surface site of adsorbent and $\mathrm{Cd}(\mathrm{II})$ is higher in higher doses resulting in the decrease of $q_{\mathrm{e}}$ value.

\section{Effect of initial concentration}

The amount of Cd(II) adsorbed per unit mass of MITDC and RT increased gradually with an increasing $\mathrm{Cd}(\mathrm{II})$ concentration of the solution (Fig. 5). By changing the initial concentration of the solution from 5 to $40 \mathrm{mg} / \mathrm{L}$, the absolute amount of adsorbed Cd(II) increased from 9.38 to $30.83 \mathrm{mg} \mathrm{Cd}(\mathrm{II})$ per gram of MITDC and from 1.99 to $7.37 \mathrm{mg}$ of $\mathrm{Cd}(\mathrm{II})$ per gram of RT, respectively. The results suggested that the maximum $q_{\mathrm{e}}$ values of MITDC and RT were 30.83 and $7.37 \mathrm{mg} / \mathrm{g}$, respectively, maintaining the environmental conditions employed in the present experiment. This trend is similar to adsorption of $\mathrm{Cd}(\mathrm{II})$ from aqueous solution by two different rock types Pumice and Scoria (Alemayehu and Lennartz 2009).

\section{Adsorption isotherms}

An adsorption isotherm is the relationship between the adsorbate in the liquid phase and the adsorbate adsorbed on the surface of the adsorbent at the equilibrium state. The equilibrium adsorption isotherms are useful in understanding the sorption interaction of importance in the design of adsorption systems. Several isotherm models such as Langmuir isotherm and the Freundlich isotherm models have been published in several literatures to describe and evaluate the experimental data of adsorption isotherms, which show the different adsorption mechanisms. In this study, the Langmuir and Freundlich isotherms were described.

The Langmuir adsorption isotherms assume that adsorption takes place at specific homogeneous sites within

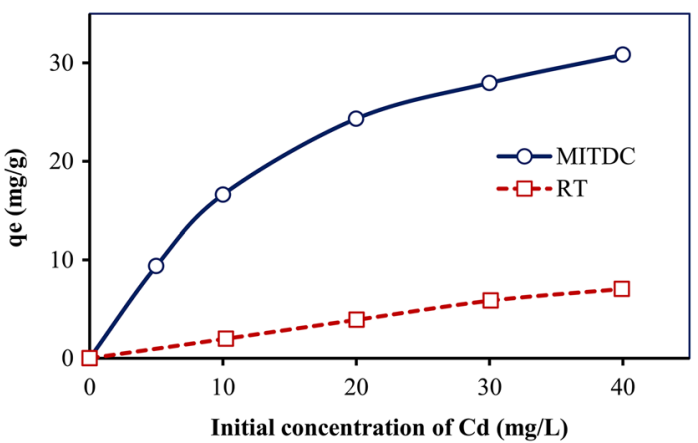

Fig. 5 Effect of initial concentration on adsorption of $\mathrm{Cd}(\mathrm{II})$ by MITDC and RT (pH 5.6, adsorbent dose $0.5 \mathrm{~g} / \mathrm{L}$ ) 
Table 1 Langmuir and Freundlich isotherm parameters for adsorption of Cd(II) by MITDC and RT

\begin{tabular}{lcl}
\hline Parameters & MITDC & RT \\
\hline Langmuir isotherm & & \\
$q_{\mathrm{m}}(\mathrm{mg} / \mathrm{g})$ & 31.25 & 9.497 \\
$b(\mathrm{~L} / \mathrm{mg})$ & 3.56 & 1.444 \\
$R^{2}$ & 0.998 & 0.996 \\
Freundlich isotherm & & \\
$k_{\mathrm{f}}(\mathrm{mg} / \mathrm{g})$ & 20.34 & 4.785 \\
$n$ & 6.94 & 2.55 \\
$R^{2}$ & 0.973 & 0.8059 \\
\hline
\end{tabular}

the adsorbent and have found successful application to many sorption process of monolayer adsorption. The Langmuir adsorption isotherm can be written as

$q_{\mathrm{e}}=\frac{q_{\mathrm{m}} b C_{\mathrm{e}}}{1+b C_{\mathrm{e}}}$

The Langmuir parameters were obtained by fitting the experimental data to the linearized equation derived from Eq. (4) which is Eq. 5 as follows:

$\frac{C_{\mathrm{e}}}{q_{\mathrm{e}}}=\frac{1}{b q_{\mathrm{m}}}+\frac{C_{\mathrm{e}}}{q_{\mathrm{m}}}$,

where $q_{\mathrm{e}}$ is the adsorbent amount ( $\mathrm{mg} / \mathrm{g}$ ) of the $\mathrm{Cd}(\mathrm{II}), C_{\mathrm{e}}$ is the equilibrium concentration of the $\mathrm{Cd}(\mathrm{II})$ in solution $(\mathrm{mg} / \mathrm{L}), q_{\mathrm{m}}$ is the monolayer adsorption capacity $(\mathrm{mg} / \mathrm{g})$, and $b$ is the constant related to the free energy of adsorption (L/mg).

Based on Eq. 5, the isotherms were fitted to the adsorption data obtained. The Langmuir adsorption exponents for Eq. 5, the $q_{\mathrm{m}}$ and $b$, are determined from the linear plots of $C_{\mathrm{e}} / q_{\mathrm{e}}$ versus $C_{\mathrm{e}}$ (Figure not shown), and the calculated correlation coefficients for these isotherms are shown in Table 1. The values of the Langmuir constant were calculated from the slopes and intercepts of the plots. The magnitude of Langmuir constant $b$ is $3.56 \mathrm{~L} / \mathrm{mg}$ for MITDC and $1.44 \mathrm{~L} / \mathrm{mg}$ for RT. The adsorption capacity $q_{\mathrm{m}}$ was determined as $31.25 \mathrm{mg} / \mathrm{g}$ for MITDC (Fig. 6a) that is larger than RT ( $9.49 \mathrm{mg} / \mathrm{g}$ ) (Fig. 6b). In order to predict the adsorption efficiency of the adsorption process, the dimensionless equilibrium parameter $R_{\mathrm{L}}$ was determined by using the following Eq. 6 (Magdy and Daifullah 1998):

$R_{\mathrm{L}}=\frac{1}{\left(1+b C_{\mathrm{i}}\right)}$,

where $C_{\mathrm{i}}$ is the initial concentration and b is the Langmuir isotherm constant. The parameter $R_{\mathrm{L}}$ indicates the shape of isotherm accordingly, as explained in Table 1. The Fig. 7 shows that the $R_{\mathrm{L}}$ values at different initial Cd(II) concentrations for MITDC indicating a highly favorable adsorption.
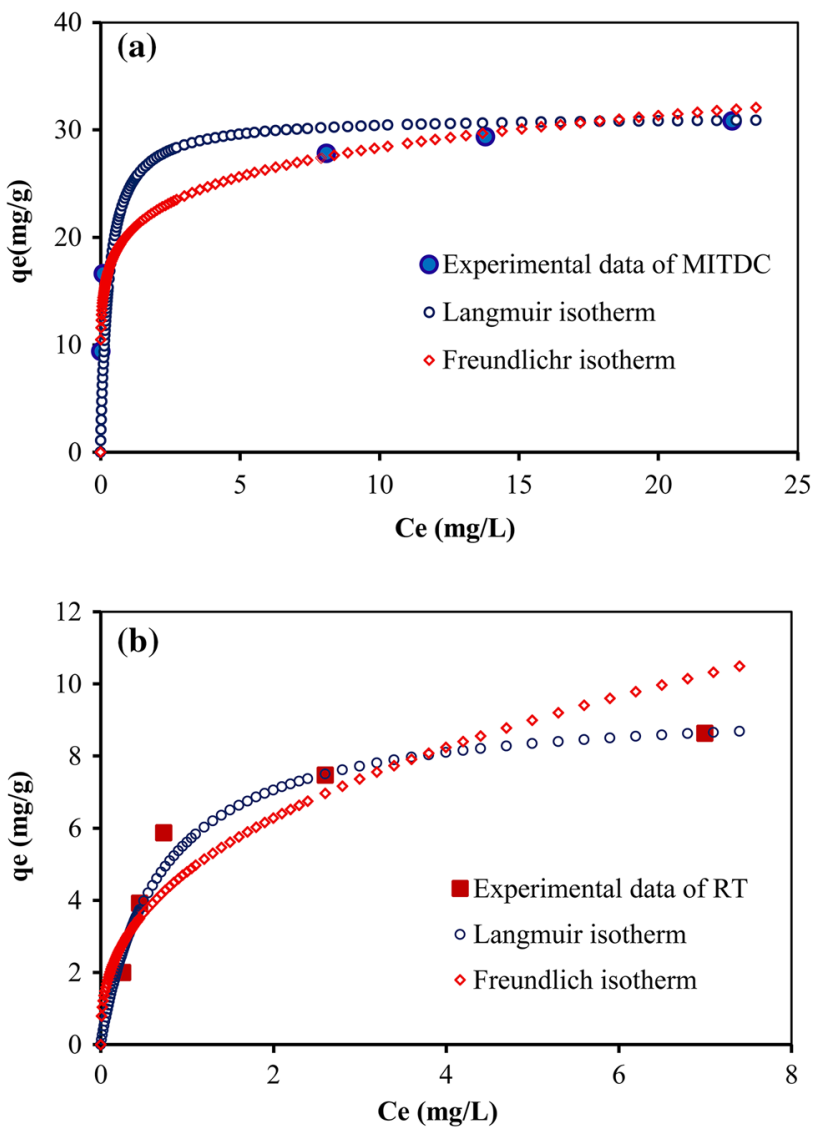

Fig. 6 Langmuir and Freundlich isotherms for Cd(II) adsorption onto MITDC (a) and RT (b) at different initial concentrations

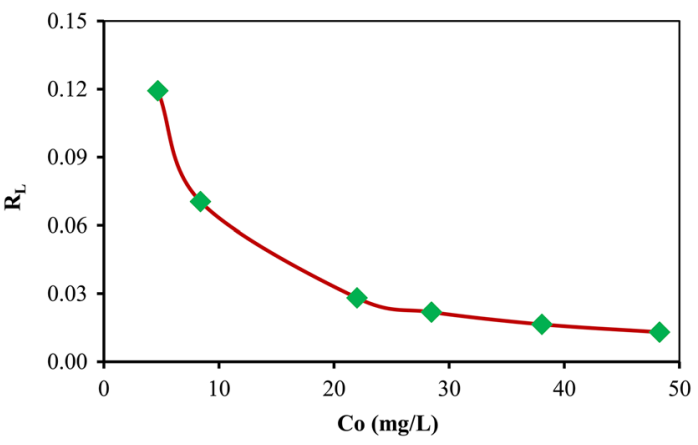

Fig. 7 Separation factor for Cd(II) adsorption by MITDC

The Freundlich isotherm is an experimental equation in use to describe heterogeneous systems:

$q_{\mathrm{e}}=K_{\mathrm{f}} C_{\mathrm{e}}^{\frac{1}{n}}$

The linearized form of Freundlich equation is

$\log q_{\mathrm{e}}=\log K_{\mathrm{f}}+\frac{1}{n} \log C_{\mathrm{e}}$,

where $q_{\mathrm{e}}$ is the adsorbent amount (mg/g) of the $\mathrm{Cd}(\mathrm{II}), C_{\mathrm{e}}$ is the equilibrium concentration of the $\mathrm{Cd}$ (II) in solution 
Table 2 A comparative Cd sorption capacities of different adsorbents related to MITDC (as literature available with us)

\begin{tabular}{llll}
\hline Adsorbent & Modifying agent & $q_{\max }(\mathrm{mg} / \mathrm{g})$ & Reference \\
\hline Tuff soil & Magnesium oxide & 31.25 & Present study (MITDC) \\
Tuff soil & - & 9.49 & Present study (RT) \\
Soil, Fox & - & 17.0 & Bolton and Evans (1996) \\
Chemically treated clay & - & 12.6 & Samir (2008) \\
Montmorillonite & - & 40.82 & Sun et al. (2014) \\
Red mud & - & 13.03 & Gupta and Sharma (2002) \\
Fly ash, treated & - & 14.33 & Chaiyasith et al. (2006) \\
Manganese nodule residue & - & 21.2 & Rout et al. (2009) \\
Low grade manganese ore & - & 59.17 & Mohapatra et al. (2008) \\
Azolla filiculoides (aquatic fern) & Magnesium chloride & 86 & Ganji et al. (2005) \\
Juniper fiber & Sodium hydroxide & 29.54 & Min et al. (2004) \\
Rice husk & Sodium hydroxide & 20.24 & Kumar and Bandyopadhyay (2006) \\
Syzygium cumini leaf powder & - & 34.54 & Rao et al. (2010) \\
Chemically modified peanut shell & - & 95.24 & Xu and Zhuang (2014) \\
\hline
\end{tabular}

$(\mathrm{mg} / \mathrm{L}), K_{\mathrm{f}}$ is the adsorption capacity of Freundlich constant $(\mathrm{mg} / \mathrm{g})$, and $\mathrm{n}$ is the adsorption intensity of Freundlich adsorption isotherm constant. The Freundlich adsorption (Fig. 6a and b) exponents for Eq. 8, the $K_{\mathrm{f}}$, and $n$, are determined from the linear plots of $\log q_{\mathrm{e}}$ versus $\log C_{\mathrm{e}}$, and the respective data are shown in Table 1 . Generally, it is stated that the values of $n$ in the range of $1-10$ represent good adsorption (Magdy and Daifullah 1998). In this study, the Freundlich constant $n$ was $1<n<10$, representing favorable adsorption.

As shown in Table 1 and Fig. 6a and b, the Langmuir equation representing adsorption process fitted very well; the correlation coefficient, $R^{2}$, value is higher for the Langmuir isotherm than that for the Freundlich isotherm, indicating a good mathematical fit (Langmuir isotherm $R^{2}=0.996$, Freundlich isotherm $\left.R^{2}=0.8059\right)$. The value of adsorption capacity of MITDC $\left(q_{\mathrm{m}} 31.25 \mathrm{mg} / \mathrm{g}\right)$ is comparatively greater than RT $\left(q_{\mathrm{m}} 9.49 \mathrm{mg} / \mathrm{g}\right)$ and some other adsorbent media developed by several studies (Table 2). Therefore, the MITDC can be used as an effective $\mathrm{Cd}$ (II) removal adsorbent from aqueous media. Saleh and Gupta (2012a, b) employed manganese dioxidecoated multiwalled carbon nanotube for removing lead(II) removal from water.

\section{Conclusions}

This study developed a novel magnesium oxide $(\mathrm{MgO})$ MITDC, which showed a high rate of $\mathrm{Cd}(\mathrm{II})$ removal capacity compared to that of the raw tuff soil (RT) from aqueous solutions. The adsorption capacity of tuff soil was significantly improved by impregnation of magnesium oxide (5\%) and heat activation. Although adsorption equilibrium data follow both Langmuir and Freundlich isotherm models, the Langmuir isotherm model fitted well with the experimental data. The capacity of $\mathrm{Cd}(\mathrm{II})$ adsorption was $31.25 \mathrm{mg} / \mathrm{g}$, calculated from Langmuir isotherm using other optimum study conditions obtained. The present adsorption kinetics clearly revealed that $\mathrm{Cd}(\mathrm{II})$ adsorption of MITDC is largely influenced by initial $\mathrm{pH}$, adsorbent amount, and initial concentration of ambient

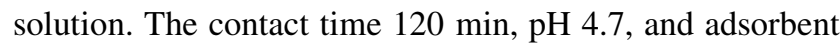
dose 7.5 were supposed to be the optimum process parameters for maximum $\mathrm{Cd}(\mathrm{II})$ adsorption of developed novel MITDC adsorbent media. The dimension less separation factor $\left(R_{\mathrm{L}}\right)$ showed that MITDC was favorable for removal of cadmium from aqueous solutions. On account of the above characteristics, it might be concluded that $\mathrm{MgO}$ MITDC can potentially be used as an easily accessible, inexpensive, and effective adsorbent media for removing high rate of cadmium from aqueous phase.

Acknowledgments The authors acknowledge the financial support provided by the Japan Society for the Promotion of Science (JSPS), Govt. of Japan as a overseas programme (Grant No. 20380181) to carry out the present study. We express our deep sense of gratitude to JSPS for this support.

Conflict of interest The author declares that there is no conflict of interests regarding the publication of this article.

Open Access This article is distributed under the terms of the Creative Commons Attribution 4.0 International License (http:// creativecommons.org/licenses/by/4.0/), which permits unrestricted use, distribution, and reproduction in any medium, provided you give appropriate credit to the original author(s) and the source, provide a link to the Creative Commons license, and indicate if changes were made. 


\section{References}

Aggarwal D, Goyal M, Bansal RC (1999) Adsorption of chromium by activated carbon from aqueous solution. Carbon 37:1989-1997

Aksu Z (2005) Application of biosorption for the removal of organic pollutants: a review. Process Biochem 40:997-1026

Alemayehu E, Lennartz B (2009) Virgin volcanic rocks: kinetics and equilibrium studies for the adsorption of cadmium from water. J Hazard Mater 169:395-401

Argun ME, Dursun S, Ozdemir C, Karatas M (2007) Heavy metal adsorption by modified oak sawdust: thermodynamics and kinetics. J Hazard Mater 141:77-85

Baes CF, Mesmer RE (1986) The hydrolysis of cations. Krieger Publishing Company, Florida

Bayrak Y, Yesiloglu Y, Gecgel U (2006) Adsorption behavior of $\mathrm{Cr}(\mathrm{VI})$ on activated hazelnut shell ash and activated bentonite. Microporous Mesoporous Mater 91:107-110

Belimov AA, Hontzeas N, Safronova VI (2005) Cadmium-tolerant plant growth-promoting bacteria associated with the roots of Indian mustard (Brassica juncea L. Czern.). Soil Biol Biochem $37: 241-250$

Benaissa H (2006) Screening of new sorbent materials for cadmium removal from aqueous solutions. J Hazard Mater 132:189-195

Benguella B, Benaissa H (2002) Cadmium removal from aqueous solutions by chitin: kinetic and equilibrium studies. Water Resour 36:2463-2474

Bhakta JN, Munekage Y (2009) Ceramic as a potential tool for water reclamation: a concise review. J Environ Prot Sci 3:147-162

Bhakta JN, Munekage Y (2011) Mercury(II) adsorption onto the magnesium oxide impregnated volcanic ash soil derived ceramic from aqueous phase. Int J Environ Res 5:585-594

Bhakta JN, Munekage Y (2013) Identification of potential soil adsorbent for the removal of hazardous metals from aqueous phase. Int J Environ Sci Technol 10:315-324

Bhakta JN, Salim M, Yamasaki K, Munekage Y (2009) Mercury adsorption stoichiometry of ceramic and activated carbon from aqueous phase under different $\mathrm{pH}$ and temperature. ARPN J Eng Appl Sci 4:52-59

Bhakta JN, Majumdar Bhakta P, Munekage Y (2014a) Development of activated carbon from cotton fibre waste as potential mercury adsorbent: kinetic and equilibrium studies. Int $\mathrm{J}$ Chem Eng. doi:10.1155/2014/176483

Bhakta JN, Rana S, Lahiri S, Munekage Y (2014b) Sorption of mercury onto waste material derived low-cost activated carbon. Appl Water Sci. doi:10.1007/s13201-014-0236-0

Bidstrup PC (1964) Toxicity of mercury and its compounds. Elsevier, Amsterdam

Bolger PT, Szlag DC (2002) An electrochemical system for removing and recovering elemental mercury from a gas stream. Environ Sci Technol 36:4430-4435

Bolton KA, Evans LJ (1996) Cadmium adsorption capacity of selected Ontario soils. Can J Soil Sci 5:183-189

Campbell PGC (2006) Cadmium—a priority pollutant. Environ Chem 3:387-388

Chaiyasith S, Chaiyasith P, Septhum C (2006) Removal of cadmium and nickel from aqueous solution by adsorption onto treated fly ash from Thailand. Int J Sci Technol 11:13-20

Fourest E, Roux J (1992) Heavy metals biosorption by fungal mycelial byproduct: mechanisms and influence of $\mathrm{pH}$. Appl Microbiol Biotechnol 37:399-403

Ganji MT, Khosravi M, Rakhshaee R (2005) Biosorption of Pb, Cd, $\mathrm{Cu}$ and $\mathrm{Zn}$ from the wastewater by treated Azolla filiculoides with $\mathrm{H}_{2} \mathrm{O}_{2} / \mathrm{MgCl}_{2}$. Int J Environ Sci Technol 1:265-271
Ghodbane I, Nouri L, Hamdaoui O, Chiha M (2008) Kinetic and equilibrium Study for the sorption of cadmium(II) ions from aqueous phase by eucalyptus bark. J Hazard Mater 152:148-158

Gupta SS, Bhattacharyya KG (2006) Removal of Cd(II) from aqueous solution by kaolinite, montmorillonite and their poly(oxo zirconium) and tetrabutylammonium derivatives. J Hazard Mater 128:247-257

Gupta UC, Gupta SC (1998) Trace element toxicity relationships to crop production and livestock and human health: implications for management. Commun Soil Sci Plant Anal 29:1491-1522

Gupta VK, Sharma S (2002) Removal of cadmium and zinc from aqueous solutions using red mud. Environ Sci Technol 36:3612-3617

Gupta VK, Srivastava SK, Mohan D, Sharma S (1998) Design parameters for fixed bed reactors of activated carbon developed from fertilizer waste for the removal of some heavy metal ions. Waste Manag 17:517-522

Gupta VK, Agarwal S, Saleh TA (2011) Synthesis and characterization of alumina-coated carbon nanotubes and their application for lead removal. J Hazard Mater 185:17-23

Gupta VK, Ali I, Saleh TA, Nayak A, Agarwal S (2012a) Chemical treatment technologies for waste-water recycling-an overview. RSC Adv 2:6380-6388

Gupta VK, Jain R, Mittal A, Saleh TA, Nayak A, Agarwal S, Sikarwar S (2012b) Photo-catalytic degradation of toxic dye amaranth on $\mathrm{TiO}_{2} / \mathrm{UV}$ in aqueous suspensions. Mater Sci Eng C $32: 12-17$

Hrudey SE, Chen W, Rousseaux CG (1995) Bioavailability in environmental risk assessment. Lewis Publishers, Boca Raton

IARC (International Agency for Research on Cancer) (1994) Beryllium, cadmium, mercury, and exposures in the glass manufacturing industry, Monographs on the Evaluation of Carcinogenic Risks to Humans. Lyon: WHO Press vol. 58, p 444

Kentish SE, Stevens GW (2001) Innovations in separations technology for the recycling and re-use of liquid waste streams. Chem Eng J 84:149-159

Kratochvil D, Volesky D (1998) Advances in the biosorption of heavy metals. Tybtech 16:291-299

Kumar U, Bandyopadhyay M (2006) Sorption of cadmium from aqueous solutions using pretreated rice husk. Bioresour Technol 97:104-109

Lackovic K, Wells JD, Johnson BB, Angove MJ (2004) Modeling the adsorption of $\mathrm{Cd}(\mathrm{II})$ onto kaolinite and Muloorina illite in the presence of citric acid. J Colloid Interface Sci 270:86-93

Lin SH, Lai SL, Leu HG (2000) Removal of heavy metals from aqueous solution by chelating resin in a multistage adsorption process. J Hazard Mater 76:139-153

Magdy YH, Daifullah AAM (1998) Adsorption of a basic dye from aqueous solutions onto sugar-industry-mud in two modes of operations. Waste Manag 18:219-226

Min SH, Han JS, Shin EW, Park JK (2004) Improvement of cadmium ion removal by base treatment of juniper fiber. Water Resour 38:1289-1295

Mittal A, Mittal J, Malviya A, Gupta VK (2009a) Adsorptive removal of hazardous anionic dye "Congo red" from wastewater using waste materials and recovery by desorption. J Colloid Interface Sci 340:16-26

Mittal A, Kaur D, Malviya A, Mittal J, Gupta VK (2009b) Adsorption studies on the removal of coloring agent phenol red from wastewater using waste materials as adsorbents. J Colloid Interface Sci 337:345-354

Mittal A, Mittal J, Malviya A, Gupta VK (2010) Removal and recovery of Chrysoidine $\mathrm{Y}$ from aqueous solutions by waste materials. J Colloid Interface Sci 344:497-507 
Mohapatra M, Khatun S, Anand S (2008) Adsorption of heavy metal ions on manganese nodule - a comparative study. Pollut Res 25:563-568

Montanher SF, Oliveira EA, Rollemberg MC (2005) Removal of lead(II) from metal ions from aqueous solutions by sorption onto rice bran. J Hazard Mater B117:207-211

Nogawa K, Kobayashi E, Okubo Y, Suwazono Y (2004) Environmental cadmium exposure, adverse effects and preventive measures in Japan. Biometals 17:581-587

Rafatullah M, Sulaiman O, Hashim R, Ahmad A (2012) Removal of cadmium(II) from aqueous solutions by adsorption using meranti wood. Wood Sci Technol 46:221-241

Rao KS, Anand S, Venkateswarlu P (2010) Cadmium adsorption from aqueous solution with agricultural waste biosorbent Syzygium cumini L leaf powder: Equilibrium and kinetic studies. Korean J Chem Eng. doi:10.1007/s11814-010-0243-2

Rout K, Mohapatra M, Mohapatra BK, Anand S (2009) Pb(II), Cd(II) and $\mathrm{Zn}(\mathrm{II})$ adsorption on low grade manganese ore. Int J Eng Sci Technol 1:106-122

Rozada F, Otero M, Moran A, Garcia AI (2008) Adsorption of heavy metals onto sewage sludge-derived materials. Bioresour Technol 99:6332-6338

Saleh TA, Gupta VK (2012a) Column with CNT/magnesium oxide composite for lead(II) removal from water. Environ Sci Pollut Res 19:1224-1228

Saleh TA, Gupta VK (2012b) Photo-catalyzed degradation of hazardous dye methyl orange by use of a composite catalyst consisting of multi-walled carbon nanotubes and titanium dioxide. J Colloid Interface Sci 371:101-106

Salim M, Son LT, Munekage Y (2008) Silica ceramic as potential adsorbent of cadmium removal from aqueous solutions. Res J Environ Sci 2:185-196
Samir IA (2008) Removal of $\mathrm{Zn}, \mathrm{Cd}$, and $\mathrm{Pb}$ Ions from water by Sarooj clay. Appl Clay Sci 42:201-205

Sari A, Tuzen M (2009) Kinetic and equilibrium studies of $\mathrm{Pb}(\mathrm{II})$ and $\mathrm{Cd}(\mathrm{II})$ removal from aqueous solution onto colemanite ore waste. Desalination 249:260-266

Srivastava S (2013) Sorption of divalent metal ions from aqueous solution by oxidized carbon nanotubes and nanocages: a review. Adv Mater Lett 4:2-8

Sun Y, Wu QT, Lee CCC, Li B, Long X (2014) Cadmium sorption characteristics of soil amendments and its relationship with the cadmium uptake by hyperaccumulator and normal plants in amended soils. Int J Phytoremed 16:496-508

Tewari N, Vasudevan P, Guha BK (2005) Study on biosorption of $\mathrm{Cr}(\mathrm{VI})$ by Mucor hiemalis. Biochem Eng J 23:185-192

USEPA (1992) Common chemicals found at superfund sites. U.S. Gov Print Office, Washington, DC: Miner Eng

Vakili M, Rafatullah M, Ibrahim MH, Abdullah AZ, Salamatinia B, Gholami Z (2014) Oil palm biomass as an adsorbent for heavy metals. Rev Environ Contam Toxicol 232:61-88

Xu L, Zhuang Z (2014) Removal of cadmium ions from aqueous solution using chemically modified peanut shell. J Chem Pharm Res 6:649-653

Zhu C, Luan Z, Wang Y, Shan X (2007a) Removal of cadmium from aqueous solutions by adsorption on granular red mud (GRM). Sep Purif Technol 57:161-169

Zhu Z-L, Ma H-M, Zhang R-H, Ge Y-X, Zhao J-F (2007b) Removal of cadmium using $\mathrm{MnO}_{2}$ loaded D301 resin. J Environ Sci 19:652-656 